\title{
A Brief Report on the First Communication Book Series Experience in Turkey
}

\author{
AHMET FARUK CECEN, Istanbul University Faculty of Communication
}

This report is penned to shed light on the cumulative efforts of a group of young academics ${ }^{1}$ in Turkey, who seek to translate the English-language literature on communication studies into Turkish, through the Communication Book Series (Altinbilek Publishing House). There have been similar and complex issues with general English communication literature reading in Turkey, not only because of cultural and linguistic differences but also because of confusion on how to translate a specific concept into Turkish, which has meant specific concepts being coined disparately by various scholars and schools. One should not think that Turkish communication scholars have not made enough effort to forming a literature that is powerful both in terms of quality (in connection with general communication literature) and quantity. A huge number of respected Turkish scholars have translated valued works of foreign scholars, and contributed to certain areas of communication, together with writing their own books and articles.

\footnotetext{
1 I would like to list the staff contributing to the Series: I, Res. Asst. Ahmet Faruk Cecen translating Communication Theory, Media, Technology, Society (2005) on my own, Cecen, Res. Asst. Rabia Zamur, Res. Asst. Serkan Bulut, Res. Asst. Gizem Orcin and Ege Oztokat translating Key Concepts in Journalism Studies (2004), Assoc. Prof. Burcu Kaya Erdem, Cecen, Bulut, Res. Asst. Taybe Topsakal, Orcin, Oztokat and Begum Erginbay translating New Media Old News: Journalism and Democracy in the Dijital Age's (2012). I would like to thank the much more experienced and informed scholars, Prof. Dr. Nurdogan Rigel and Prof. Dr. Ali Murat Vural, who not only gave advice on the Series but also showed the kindness to join our Series. Professor Rigel, with her vast knowledge of cultural theory accepted to edit David Walton's "Doing Cultural Theory", and Professor Vural will write an article, reflecting on the knowledge he gained of the news gathering process from being the assistant of Ugur Mumcu, the legendary journalist, who is famous with investigative journalism in Turkey. It is also important to say that Ilker Balkan, the director of the Altinbilek Publishing House, not only gave us inspiration but also has been always here to help us. I also would like to thank Bulut, who is the editor of the book about news gathering and reporting in our Series, for helping me shape the future of the Series and my wife, Fulya Cecen for providing insight.
} 


\section{Aims: Common Ground and Common Language}

As mentioned above, the general problem with communication studies in Turkish is not having common ground. There are respected and valued studies but they do not possess a common language to help scholars improve communication literature in Turkey. One of the most effective ways to sort out the abovementioned problem is by conducting a joint scientific study group of media academics. That purpose provided inspiration for the Series.

\section{Books We Have Been Translating}

Considering the main purpose of this Series: (formation of a common language that would help Turkish media academics to improve literature), it was inevitable to start this Series with a key concepts book. Picking up Richardson, Kinsey, Hanna, Hamer and Franklin's Key Concepts in Journalism Studies (2004) is both a reflection of the quality of the book and a reaction to the domination of the American school in the Turkish communication environment, where (according to my own observations) other schools are consequently being ignored on a large scale by Turkish scholars. Just like the Series, this book also holds the distinction of being the first dictionary-type communication book to be translated into Turkish.

As Steve Jones says of Holmes' Communication Theory: Media, Technology, Society (2005): "There is no other book that can both be used as a teaching tool and can help scholars organize their thinking about new media." Holmes' work is important for understanding the differences and the interrelations between the first and second media ages. Considering Holmes' effort to involve first media age theorists, some of whom might be exemplified by Adorno, Althusser, Debord, Baudrillard and McLuhan, together with second media age theorists, it is obvious that its being translated into Turkish provides a great deal of opportunities we sought to have at the start of the Series, such as translating various theorists' concepts into Turkish and getting experts views on their perspectives. Thanks to Holmes' work, scholars of Turkish communication literature will meet various scholars whose thoughts on communication are unfamiliar to them, at least as translated concepts. 
It would be unfair to say that phenomena such as new media, social media, citizen journalism and journalism in the new media era have been ignored by Turkish scholars; however, there is no other book answering questions in the way that the authors of New Media, Old News: Journalism and Democracy in the Digital Age (2012) have done: "Have new communications technologies revitalized the public sphere, or become the commercial tool for an increasingly un-public, undemocratic news media? Are changing journalistic practices damaging the nature of news, or are new media allowing journalists to do more journalism and to engage the public more effectively." Providing a comprehensive guide to theories of communication over the last 40 years, locating them in relation to associated disciplines such as media studies and computer-mediated communication (Pelletier, 2006), Holmes' work is admittedly a reference book to understand communication theory, but its focus is not on the relation between internet and journalism practice. New Media, Old News: Journalism and Democracy in the Digital Age's editor, Natalie Fenton, and other scholars not only answered the typical questions about the rise of new technologies and the changing news, but they also managed to discuss what the concepts that belong to the first media age (such as political economy of news, news sources, the liberal-pluralist approach to media and journalism ethics) mean in the new media era. It can be argued that translating this book gives the chance to Turkish scholars to compare English and Turkish media organizations' positions in this particular era.

\section{Prospective Translation Books}

As a group, we have tried to choose books which can get to fill the gap which we think exists in our literature. As already mentioned, we are really happy with Professor Rigel's decision to edit Walton's Doing Cultural Theory, which is going to fill a massive gap in cultural theory studies at this point in Turkey. Speaking of highly ignored areas, framing would be in the forefront in Turkey. Projections of Power: Framing News, Public Opinion, and U.S. Foreign Policy by Robert M. Entman, a highly prominent scholar in framing methods, will help scholars studying in this specific area. As a highly used method, framing is important, but it can be claimed that a general research methods book on media and communication studies is necessary for a communication book series; therefore we been trying to find the book on this specific area which can help us best. 


\section{Things to Decide Before Translating}

There is so much to state about the experience of translating key communications texts into Turkish. There are decisions to be made before or during this process. One can be speculative by changing the original meaning the author meant to convey in the first place, so that it would be more understandable to Turkish readers, or one can stick to the original. As an example, a prominent communication scholar, Unsal Oskay, translated McLuhan's The Medium is the Message into Turkish as Yaradınımız Medya (Our Creator is Media), which is more suitable for Turkish people to understand. Considering that he is one of the most important communication scholars, Oskay's being speculative and turkifying terms and concepts is understandable, but we generally tried to stick to the original meaning. On the occasions that we have to turkify a concept we give an explanation with it.

\section{What Can We Do But Translating?}

However, translating books per se is not enough to explain the aims and objectives of the Series. We have been jointly preparing a book on news gathering and reporting, a collective work between academics and working journalists, which will be the first book written by us to be published in this series, but not the only one. After this book, our goal, based on the experience we've gained through previous works in this particular series, is to publish more theoretical books, just like those that have already been translated, in a way that attracts both academics from various branches in communication and foreign scholars.

\section{References}

Franklin, B., Martin Hamer, Mark Hanna, Marie Kinsey and John E Richardson (Ed.). (2005). Key Concepts in Journalism Studies. Sage.

Holmes, D. (2005). Communication Theory: Media, Technology and Society. Sage.

Natalie Fenton (Ed.). (2009). New Media, Old News: Journalism and Democracy in the Digital Age. Sage Publications 
Pelletier, C. (2006). Book Review: “Communication Theory: Media, Technology and Society. by David Holmes. Cambridge Journal of Education, 36(1), 145-146.

$\underline{10.1080 / 03057640500491146}$

Ahmet Faruk Cecen is PHD student and research assistant in Istanbul University Faculty of Communication and editor of Communication Books Series in Turkey. His research focuses on perception, discourse, communication theory, foreign news, international communication and conspiracy theories.

Email: faruk.cecen@istanbul.edu.tr,$\underline{\text { ahmetfarukcecen1@gmail.com }}$ 